\title{
IAMJ
}

INTERNATIONAL

AYURVEDIC

MEDICAL JOURNAL

\section{EVALUATION OF ANTI-HISTAMINIC ACTIVITY OF KASANKUSHA RASA IN GUINEA PIGS}

\section{$\underline{\text { Divya Shekar. }}^{1}$, Surekha S Medikeri²}

${ }^{1}$ PG Scholar, Dept of Rasashastra and Bhaishajya Kalpana, Government Ayurveda Medical College, Bengaluru, Karnataka, India

${ }^{2}$ Professor and HOD, Dept of Rasashastraand Bhaishajya Kalpana, Government Ayurveda Medical College, Bengaluru, Karnataka, India

Corresponding Author: divyashekar.b@gmail.com

\section{https://doi.org/10.46607/iamj1609092021}

(Published Online: September 2021)

Open Access

(C) International Ayurvedic Medical Journal, India 2021

Article Received:02/09//2021 - Peer Reviewed:11/09/2021 - Accepted for Publication:12/09/2021

\section{Check for updates}

\begin{abstract}
Many formulations in Rasashastra textbooks are indicated for allergic conditions like Bronchial Asthma. Rasaushadhis are more effective than herbal preparations owing to their infinite shelf life, lower dose, faster action and palatability ${ }^{1}$. Kasankusha rasa is a Kharaliya preparation indicated in various conditions of Shwasa and Kasa as per the reference of Rasa Yoga Sagara ${ }^{2}$ which is composed of Hingula, Maricha, Mustha, Vatsanabha and Tankana. It is chosen for the present study, focusing on its Anti-Histaminic effect. Instead of using Kajjali which is a tedious procedure to prepare as in other formulations, this yoga contains ShuddhaHingula thus easing the procedure. Hence, an attempt is made to validate the classical indications of the formulation to the current biomedicine scenario.
\end{abstract}

Keywords: Kasankusha rasa, Rasashastra, Shwasa,Kasa, Anti-Histaminic activity 


\section{INTRODUCTION}

Bronchial Asthma is a chronic, inflammatory disease of the airways, characterized by airflow obstruction, bronchial hyperactivity and mucous production. It is a global health problem as per WHO, affecting all age groups. About $250-300$ million people suffer worldwide ${ }^{3}$. Deaths from this condition have reached over 3,83,000 annually ${ }^{4}$. Some of the postulated reasons for upper and lower respiratory tract allergic diseases are increasing environmental pollution ${ }^{5}$ and increased predisposition of individuals producing excessive IgE through a major change in the gene pool, changing lifestyles, and non-judicious use of antibiotics and corticosteroids in the contemporary system of medicines leading to suppression of host immunity and birth of multidrug-resistant traits of pathogens, which in turn results in recurrence of RTI. H 1 - Histamine antagonists are used in the management of allergic conditions like Urticaria, Rhinitis and Bronchial Asthma which show good clinical efficacy in alleviating allergic symptoms, however, their use is limited by poor tolerability, due to their anticholinergic activity and sedative properties and unfortunately, none of these treatment modalities provides a permanent cure and has their limitations. Despite spending millions on effective antihistamine drugs, biomedicine suffers major drawbacks in comprehensive allergic control. Hence, there is great scope for Ayurveda to offer safe and effective allergy management. Rasashastra is an offshoot of Ayurve$d a$, and it is having the credential of revolutionizing Indian pharmaceutics, by inventing the medicinal values of minerals and rendering inorganic minerals into bio acceptable therapeutically valuable medicines.

Hence in the present study, Kasankusha rasa is prepared and experimentally evaluated for its AntiHistaminic activity in guinea pigs.

\section{METHODOLOGY}

\section{Preparation of test drug:}

Kasankusha rasa was prepared in the Dept of Rasashastra and Bhaishajya Kalpana, GAMC, Bengaluru. The fine powder of Shodhita Hingula, Vatsanabha, Tankana, Maricha and Musta have tritu- rated in a khalva yantra with Jambeera rasa till it attains vati lakshana ${ }^{6}$. Pills of Mudga pramana (approx. $45 \mathrm{mg}$ ) were rolled, dried in shade and stored in an airtight container.

\section{Experimental Animals:}

Adult healthy guinea pigs of either sex weighing about 350-400g, procured from Biogen laboratory animal facility, Bengaluru. They were fed and housed as per OECD guidelines. The animals were randomly selected and kept in a cage for 5 days before dosing to allow for acclimatization to the laboratory conditions. The animal protocol was obtained from Institutional Animal Ethics Committee (IAEC) with reference no. PESCP/IAEC/114/2020. The experimental study was carried out in PES College of Pharmacy, Bengaluru.

\section{Dose of standard and trial drug ${ }^{7}$}

$>$ Based on various research publications available the dose of standard drug Chlorpheniramine maleate was fixed as $2 \mathrm{mg} / \mathrm{kg}$ body weight of guinea pigs.

$>$ The human dose of the trial drugs was converted to an animal dose based on a standard dose converting formula.

$>$ The human dose of KR $-45 \mathrm{mg} /$ day $(45 / 60 \mathrm{~kg}$ $=0.75 \mathrm{mg} / \mathrm{kg} \mathrm{bw})$

$>$ Guinea pig $(\mathrm{mg} / \mathrm{kg}$ bw) = Human dose $(\mathrm{mg} / \mathrm{kg}$ bw) $x K_{m}$ ratio

$>$ Guinea pig dose $=0.75 \mathrm{mg} \times 4.6=3.45 \mathrm{mg} / \mathrm{kg}$ bw po is the medium dose.

\section{EXPERIMENTAL TRIAL PROPER:}

\section{Study Design:}

The effect was assessed by

a. Histamine induced broncho-constriction in guinea pigs.

b. Haematological evaluation

c. Lung tissue parameters

a. Histamine induced Bronchoconstriction in guinea pigs ${ }^{8}$ :

Procedure:

$>$ Overnight fastened guinea pigs were divided into five groups each consisting of six animals. All treatments were made orally. 
Group 1- Normal Vehicle (Ginger Juice)

Group 2- Disease Control (ovalbumin)

Group 3- Kasankusha rasa + Ginger juice

Group 4- Kasankusha Rasa

Group 5- Standard (chlorpheniramine maleate).
Sensitization involved administering $500 \mu \mathrm{l}$ ovalbumin intraperitoneally on the $0,7^{\text {th }}$ and $14^{\text {th }}$ day. On days $21,22,23$ of the experiment, guinea pigs were challenged by aerosolizing them with $1 \mathrm{mg} / \mathrm{ml}$ of OVA for $15 \mathrm{~min}$ by placing the animal in a histamine chamber connected to a nebulizer.

Table 1: Showing the study design

\begin{tabular}{|c|c|c|c|c|c|}
\hline Gp & GP No & Group Name & Dose and Route & Dose frequency & Duration \\
\hline I & $1-6$ & Normal vehicle- GJ & $2 \mathrm{ml} / \mathrm{kg}$ bw po & Daily (1-23) & 23 days \\
\hline \multirow[t]{3}{*}{ II } & \multirow[t]{3}{*}{$7-12$} & \multirow[t]{2}{*}{ Ovalbumin- Control } & $500 \mu$ l OVA solution i.p & $0,7^{\text {th }}$ and $14^{\text {th }}$ day & 3 days \\
\hline & & & OVA aerosol & Daily for $15 \min (21-23)$ & 3 days \\
\hline & & Normal vehicle- GJ & $2 \mathrm{ml} / \mathrm{kg}$ bw po & Daily (1-23) & 23 days \\
\hline \multirow[t]{3}{*}{ III } & \multirow[t]{3}{*}{$13-18$} & \multirow[t]{2}{*}{ Ovalbumin- Control } & $500 \mu$ l OVA solution i.p & $0,7^{\text {th }}$ and $14^{\text {th }}$ day & 3 days \\
\hline & & & OVA aerosol & Daily for $15 \min (21-23)$ & 3 days \\
\hline & & $\mathrm{KR}+\mathrm{GJ}$ & $3.45 \mathrm{mg} / \mathrm{kg}$ bw po & Daily (1-23) & 23 days \\
\hline \multirow[t]{3}{*}{ IV } & \multirow[t]{3}{*}{$19-24$} & \multirow[t]{2}{*}{ Ovalbumin- Control } & $500 \mu$ l OVA solution i.p & $0,7^{\text {th }}$ and $14^{\text {th }}$ day & 3 days \\
\hline & & & OVA aerosol & Daily for $15 \min (21-23)$ & 3 days \\
\hline & & KR without GJ & $3.45 \mathrm{mg} / \mathrm{kg}$ bw po & Daily (1-23) & 23 days \\
\hline \multirow[t]{3}{*}{$\mathrm{V}$} & \multirow[t]{3}{*}{$25-30$} & \multirow[t]{2}{*}{ Ovalbumin- Control } & $500 \mu$ l OVA solution i.p & $0,7^{\text {th }}$ and $14^{\text {th }}$ day & 3 days \\
\hline & & & OVA aerosol & Daily for $15 \min (21-23)$ & 3 days \\
\hline & & CPM & $2 \mathrm{mg} / \mathrm{kg}$ bw po & Daily (1-23) & 23 days \\
\hline
\end{tabular}

Measurement of allergic response- On the $24^{\text {th }}$ day, they fasted overnight. The following day, the animals in each group were exposed to $1 \% \mathrm{w} / \mathrm{v}$ histamine aerosol using a nebulizer at a pressure of $300 \mathrm{mmHg}$ in an air-tight plexiglass chamber. This caused progressive signs of difficulty in breathing leading to asphyxia. The time of onset of asphyxia was recorded. The time taken for each animal to fully recover was also measured as the recovery time (RT). The percentage protection offered by the treatment against asphyxia was calculated, using the formula:

Percentage protection $=\left[\left(T_{2}-T_{1}\right) / T_{2}\right] \times 100$

Where $T_{1}$ is the time of onset of asphyxia before drug treatment

\section{OBSERVATIONS AND RESULTS}

Table 2: Showing percentage protection against histamine-induced allergy in normal and treated guinea pigs

\begin{tabular}{|l|l|l|}
\hline Group No & Group name & $\mathbf{\%}$ Protection \\
\hline I & Normal vehicle & $4.09 \pm 1.03$ \\
\hline II & OVA control & $3.15 \pm 1.85^{\text {ns }}$ \\
\hline III & KR+GJ treated & $27.37 \pm 3.05^{* * *}$ \\
\hline IV & KR treated & $21.74 \pm 5.19^{* * *}$ \\
\hline V & CPM treated & $32.46 \pm 1.96^{* * *}$ \\
\hline
\end{tabular}

$T_{2}$ is the time of onset of asphyxia after drug treatment

Then the results were subjected to statistical analysis.

\section{b. Haematological evaluation:}

Blood sampling-At the end of the study, the blood was withdrawn from the lateral saphenous vein and used for the estimation of total WBC count and differential leukocyte count (DLC).

\section{c. Evaluation of Lung tissue parameters-}

Procedure: The lung tissue was homogenized, then the content was transferred into Eppendorf tubes and centrifuged at $10,000 \mathrm{rpm}$ for $10 \mathrm{~min}$ at $4^{\circ} \mathrm{C}$. The clear supernatant was used for the estimation of oxidative stress markers - lipid peroxidation, reduced glutathione, superoxide dismutase, and catalase. 
Table 3: Showing effects on WBC count, LYM\%, MID \% and platelets.

\begin{tabular}{|l|l|l|l|l|}
\hline Gp No & Group Name & $\begin{array}{l}\text { WBC } \\
\mathbf{( 1 0} / \mathbf{\mu L})\end{array}$ & $\begin{array}{l}\text { LYM } \\
(\mathbf{\%})\end{array}$ & $\begin{array}{l}\text { MID } \\
(\mathbf{\%})\end{array}$ \\
\hline I & Normal vehicle & $3.85 \pm 0.23$ & $42.83 \pm 1.94$ & $8.38 \pm 1.33$ \\
\hline II & OVA control & $32.20 \pm 2.12^{* * *}$ & $75.06 \pm 4.14^{* * *}$ & $5.80 \pm 1.09^{\mathrm{ns}}$ \\
\hline III & KR+GJ treated & $6.70 \pm 0.35^{* * *}$ & $43.23 \pm 10.61^{* * * *}$ & $9.43 \pm 2.41^{*}$ \\
\hline IV & KR treated & $3.78 \pm 0.09^{* * *}$ & $82.66 \pm 3.06^{\mathrm{ns}}$ & $5.43 \pm 1.15^{\mathrm{ns}}$ \\
\hline V & CPM treated & $10.45 \pm 0.81^{* * *}$ & $62.53 \pm 17.74^{\mathrm{ns}}$ & $9.43 \pm 3.85^{*}$ \\
\hline
\end{tabular}

Table 4: Showing effects on RBC count, HGB, HCT, MCV, MCH and MCHC in normal and treated guinea pigs.

\begin{tabular}{|c|c|c|c|c|c|c|c|}
\hline \multirow{2}{*}{$\begin{array}{l}\text { GpN } \\
\text { o }\end{array}$} & \multirow{2}{*}{$\begin{array}{l}\text { Gp } \\
\text { name }\end{array}$} & \multicolumn{6}{|c|}{ Hematological parameter } \\
\hline & & $\begin{array}{l}\text { RBC } \\
\left(10^{6} / \mu L\right)\end{array}$ & $\begin{array}{l}\text { HGB } \\
(\mathrm{g} / \mathrm{dL})\end{array}$ & $\begin{array}{l}\text { HCT } \\
(\%)\end{array}$ & $\begin{array}{l}\text { MCV } \\
\text { (fL) }\end{array}$ & $\begin{array}{l}\text { MCH } \\
\text { (pg) }\end{array}$ & $\begin{array}{l}\text { MCHC } \\
(\mathrm{g} / \mathrm{dL})\end{array}$ \\
\hline I & $\begin{array}{l}\text { Vehi- } \\
\text { cle }\end{array}$ & $5.50 \pm 0.10$ & $20.43 \pm 1.55$ & $56.86 \pm 1.04$ & $103.33 \pm 0.35$ & $37.07 \pm 3.16$ & $35.90 \pm 3.04$ \\
\hline II & $\begin{array}{l}\text { OVA } \\
\text { control }\end{array}$ & $\begin{array}{l}4.07 \pm 0.04 * * \\
*\end{array}$ & $\begin{array}{l}16.03 \pm 0.32 * * \\
*\end{array}$ & $\begin{array}{l}38.25 \pm 0.52 * * \\
*\end{array}$ & $\begin{array}{l}93.95 \pm 0.36^{* *} \\
*\end{array}$ & $39.28 \pm 0.46^{*}$ & $\begin{array}{l}41.86 \pm 0.38 * * \\
*\end{array}$ \\
\hline III & $\begin{array}{l}\mathrm{KR}+\mathrm{G} \\
\mathrm{J}\end{array}$ & $\begin{array}{l}5.74 \pm 0.28 * * \\
*\end{array}$ & $18.06 \pm 0.88^{* *}$ & $\begin{array}{l}53.06 \pm 2.95 * * \\
*\end{array}$ & $\begin{array}{l}92.45 \pm 0.62 * * \\
*\end{array}$ & $\begin{array}{l}31.41 \pm 0.19 * * \\
*\end{array}$ & $34.00 \pm 0.26 * * *$ \\
\hline IV & $\begin{array}{l}\mathrm{KR} \\
\text { treated }\end{array}$ & $\begin{array}{l}4.45 \pm 0.03 * * \\
*\end{array}$ & $14.38 \pm 0.14 * *$ & $41.56 \pm 0.38 * *$ & $93.51 \pm 0.07^{\mathrm{ns}}$ & $\begin{array}{l}32.25 \pm 0.08 * * \\
*\end{array}$ & $34.55 \pm 0.10 * * *$ \\
\hline V & $\begin{array}{l}\mathrm{CPM} \\
\text { treated }\end{array}$ & $\begin{array}{l}4.64 \pm 0.17 * * \\
*\end{array}$ & $15.16 \pm 0.65^{\mathrm{ns}}$ & $\begin{array}{l}44.75 \pm 1.82 * * \\
*\end{array}$ & $\begin{array}{l}96.43 \pm 0.28 * * \\
*\end{array}$ & $\begin{array}{l}32.58 \pm 0.20 * * \\
*\end{array}$ & $33.83 \pm 0.24 * * *$ \\
\hline
\end{tabular}

Table 5: Showing effects on lung tissue parameters.

\begin{tabular}{|l|l|l|l|l|l|}
\hline GpNo & Gp name & $\begin{array}{l}\text { LPO }(\mathbf{n M} / \mathbf{m g} \text { pro- } \\
\text { tein) }\end{array}$ & $\begin{array}{l}\text { GSH (U/mg pro- } \\
\text { tein) }\end{array}$ & $\begin{array}{l}\text { SOD (U/mg pro- } \\
\text { tein) }\end{array}$ & $\begin{array}{l}\text { Catalase (U/mg pro- } \\
\text { tein) }\end{array}$ \\
\hline I & Vehicle treated & $1.65 \pm 0.54$ & $34.35 \pm 1.15$ & $18.05 \pm 0.14$ & $493.12 \pm 24.02$ \\
\hline II & OVA control & $20.40 \pm 2.03 * * *$ & $6.50 \pm 0.50 * * *$ & $5.31 \pm 0.98 * * *$ & $113.62 \pm 27.13 * * *$ \\
\hline III & KR+GJ treated & $4.72 \pm 0.70^{* * *}$ & $26.75 \pm 0.72 * * *$ & $12.53 \pm 0.37 * * *$ & $377.75 \pm 33.90 * * *$ \\
\hline IV & KR treated & $6.96 \pm 0.96 * * *$ & $24.30 \pm 0.58 * * *$ & $11.19 \pm 0.53 * * *$ & $330.50 \pm 25.12 * * *$ \\
\hline V & CPM treated & $3.47 \pm 0.43 * * *$ & $29.54 \pm 0.26 * * *$ & $14.93 \pm 0.48 * * *$ & $437.37 \pm 36.55^{* * *}$ \\
\hline
\end{tabular}

\section{DISCUSSION}

Discussion on Experimental model:

Guinea pigs are used in the study, because of sensitivity and close anatomical and physiological association, which exists between tracheal and bronchial musculature, and Receptor pharmacology in guinea pigs more closely matches that of human receptor pharmacology than other commonly used species.

Discussion on Efficacy of test drugs on Histamine induced bronchospasm in guinea pigs:

$>$ Delayed onset of pre-convulsive dyspnoea time in Group III, IV, V trial groups

$>$ Kasankusha rasa showed maximum percentage protection of $27+/-3.05 \%$. this may be due to ashukari/quick action of rasoushadhi.

$>$ Kasankusha rasa with vehicle showed better protection than kasankusha rasa plain and the difference between them is significant, substantiating the claim of Acharyas that Anupana/Sahapana potentiates the action of the main drug.

Discussion of Effects of test drugs on Haematological parameters:

WBC count -Increased WBC count can indicate Infection, inflammation, tissue damage or stress. ${ }^{9}$ Significant increase of WBC was seen in 
Group II.

Lymphocyte count-Increased lymphocyte is a feature of infection/ allergic reactions. A significant increase in lymphocyte count was observed in group II. MID count- Increased count of MID is seen in acute infection/ allergic reactions/ asthma. A nonsignificant increase in group II animals was seen.

RBC count- Lower levels of RBC counts were associated with asthma and allergic disease. ${ }^{10}$ The guinea pigs of group II showed a significant decrease in RBC count.

Haemoglobin count $-\mathrm{Hb}$ levels increases in lung tissue damage, COPD etc., as an adaptive physiological response to hypoxia, which stimulates the production of mature RBCs from the bone marrow. ${ }^{11} \mathrm{Sig}$ nificant decreases in $\mathrm{Hb}$ levels were seen in group IV and $\mathrm{V}$ when compared to group II.

MCV count - MCV increases in hypoxia. ${ }^{12} \mathrm{~A}$ significant increase in MCV in group II guinea pigs was observed when compared to group III animals.

MCH count and MCHC count- There is increased $\mathrm{MCH}$ and MCHC in group II animals may be because of tissue damage leading to hypoxia which promotes erythropoiesis, which causes secondary polycythemia $^{13 .}$

c. Discussion on Effects of test drugs on Lung tissue parameters:

Lipid peroxidation: Lipid peroxidation is oxidative damage that affects cellular membranes, lipoproteinsin conditions with oxidative stress often precedes irreversible cell damage. The guinea pigs of group II showed increased levels.

Glutathione: GSH is one of the fundamental antioxidants defense mechanisms in oxidant-induced lung injury and inflammation. The guinea pigs of groups III, IV, and V have shown a significant increase in glutathione levels.

Superoxide dismutase: The superoxide dismutases (SOD) play a pivotal role in protecting tissues from damage by oxidant stress by scavenging superoxide anion, which prevents the formation of other more potent oxidants. The guinea pigs of groups III, IV, and $\mathrm{V}$ have shown a significant increase in SOD levels.
Catalase: Catalase, plays a central role in the antioxidant screen of the lungs by its ability to convert hydrogen peroxide to oxygen and water. Hydrogen peroxide is a harmful byproduct of many normal metabolic processes ${ }^{14}$ The guinea pigs of groups III, IV, and V have shown a significant increase in catalase levels.

\section{PROBABLE MODE OF ACTION OF} KASANKUSHA RASA IN SHWASA:

Tamaka shwasa is a Pranavaha srotas vyadhi where the Vayu gets vitiated from its normalcy due to obstruction made by Kapha. Hence the treatment principles adopted should normalise Vata and Kapha and increase Agni to remove obstruction in Strotas. In the present study of Kasankusha rasa, except indications, there is no reference of rasa, guna, virya etc of this formulation. Hence the $R a$ sa, Guna, Virya etc. which were described for individual drugs are considered, so we can establish the possible properties, actions, and mode of action of our trail drugs by observing their pharmacological effects.

\section{By its Rasa:}

Katu rasa: Hingula, Vatsanabha, Tankana, maricha, musta and Ardrakaswarasa (used in Hingulashodhana) present in Kasankusha rasa has Katurasa. Katu rasa is predominant in Vayu and Agni Mahabhoota which tend to act in an upward direction. It also as Shothahara (anti-inflammatory), Kanduvinashana (antihistamine), Kriminhinasthi, Marganvivrunoti (broncho-dilator), Kleda-Kapha-Malanupahanti (expectorant) ${ }^{15}$.

Kashaya rasa: Hingula, Vatsanabha Musta, Gomutra (used in Vatsanabhashodhana) has Kashaya rasa. It helpsin the alleviation of kapha dosha of respiratory airway disorders and does Shoshana (dries up excessive secretions $)^{19}$.

\section{By its Guna:}

TeekshnaGuna: Vatsanabha, Maricha, Tankana, Gomutra has Teekshnaguna (penetrativequality). Teekshna guna has Agni mahabhoota dominanace which is Kaphagna (mucolytic-mucokinetic) and Shodhaka (expectorant effect) and is very rare essential pharmacological activities intreating Kasa and Shwasaroga.

Laghu, Rukshaguna: Gomutra, Vatsanabha, Tankana, Musta, Maricha has Laghu, Ruksha guna. It helps to 
clear the inflammation, congestion and inhibits the excessive secretions and discharges.

Vyavayi, Vikasi guna: Vyavayi and vikasiguna of Vatsanabha account for quick absorption and easy transportation of the drug into the cell membrane.

\section{By Virya:}

Ushna virya: Hingula, Vatsanabha, Maricha, Tankana, Jambeera, Ardraka and Gomutra has Ushna veerya (hot potency). It helpsin Pachana (digestive), Swedana (diaphoretic), Vilayana (Iiquification), expectorant, Kaphagna (reducesphlegm), Lekhana (scraping)and as potent Vatakaphashamaka property ${ }^{16}$.

\section{By its Karma:}

Vishahara and Ojovardhaka: Shwasa can be nidanarthakara roga of many other diseases and can also be because of Visha.Amashayastha dushivisha can cause secondary doshadusti and can lead to Amashayastha kapha vata vikaras likeSshwasa. Vishahara property and Ojo vardhaka property help to counteract the primary pathogenesis of Visha and Ojovyapat. Kasankusha rasa containing, Hingula, Tankana, Gomutra as Vishaharaguna.

Deepana and Pachana:Origin of Shwasa is from Aamashaya which is Pittasthana and correction of Pitta or Agni is done by Deepana guna. Hingula, Maricha, Vatsanabha, Musta, Jambeera, Ardraka, Gomutra has Deepana, Pachanaguna.

Rasayana: Hingula and Vatsanabha is a Rasayana most useful in all treatable cases of Shwasa roga.

\section{By Doshgnata:}

\section{Kapha-vatagna properties:}

> Hingula, Vatsanabha, Tankana, Musta, Maricha, Jambeera, Ardraka, Gomutra has Kaphavatagna property, which helps in removing the Malaroopi kapha from Pranavaha srotas, thereby clearing the passage of Prana and normalising Samana vayu in Pranavaha srotas

In total, all the ingredients of Kasankusha rasa are synergistically a potent fast-acting drug having $\mathrm{Va}$ takaphahara, Vatanulomaka, Marga Vivarana, Deepana, Pachana, Balya, Brimhana, Kasa Shwasahara, Rasayana effect. Hence Kasankusha rasa is found to be a promising drug in the treatment of Shwasa.

\section{CONCLUSION}

$>$ In Histamine induced allergic response, Kasankusha rasa showed significant percentage protection. Kasankusha rasa with anupana (ardraka swarasa) showed a better response than Kasankusha rasa plain, which is statistically significant.

$>$ Lung tissue parameters showed: Increased levels of glutathione, super-oxide dismutases and catalase in groups III, IV and V. The guinea pigs of groups III, IV, and V have shown a significant decrease in lipid peroxidation level

With the factual evidence obtained by experimental data, it has been concluded that Kasankusha rasa is an effective Anti-Histaminic drug and Anupana augments Drug action.

\section{REFERENCES}

1. Gopal Krishna. Rasendra Sara Sangraha, Edited by Ambikadatta Shastry. Benaras: Chowkambha Sanskrit Series; Chapter 1, Verses 4, Pp 2.

2. Pandit Hariprapannaji. Rasayoga Sagara. Varanasi: Chowkambha Krishnadas Academy Publications; Reprint 2004. Vol 1. Verses 1139, Pp 299.

3. www. who.int visited on 21/3/2019

4. Vishwanath R Prasad M, Thakur AK. Epidemiology of asthma in an urban population: random morbidity survey. Journal of Indian Medicine Association 1996; 46: 480-3(PubMed).

5. D'Amato G.: Environmental urban factors (air pollution and allergens) and the rising trends in allergic respiratory diseases, allergy .2002, 57, 30-33

6. Govindas. Bhaishajya Ratnavali. Varanasi: Chowkambha Sanskrit series; 2017. Vol 2, Chapter 29/9598, page no.303

7. Anroop B. Nair, and Shery Jacob. A simple practice guide for dose conversion between animals and humans. Journal of Basic and Clinical Pharmacy. 2016;7(2): 27-31.

8. Patel KG, Patel KV, Shah JH, Monpara KB, Gandhi TR. Evaluation of the effect of Myricasapida on bronchoconstriction and bronchial hyperreactivity. Pharmazie.2008; 63:312-6.

9. https://blog.insidetracker.com/45247913486-highwhite-blood-cell-count-what-you-should dated on 21/6/2021

10. Zimmerman GA. Hypoxic erythrocytes spark lung 
leukocyte adhesion. Blood. 2008; 111:4831-4832. Doi:10.1182/blood-2008-02-140947 (PubMed)

11. Yajin Zhao, Xiang Wang, Milody Noviana, Man Hou. Nitric oxide in red blood cell adaptation to hypoxia. Acta Biochimica et Biophysica Sinica, Volume 50, issue 7.7.2018, pages 621-634.

12. Tsantes. A.R, Papadhimitriou. S.I, Tassiopoulos S.T, Bonovas S, Paterakis G, Meletis I and Loukopoulos.D (2004). Red cell macrocytosis in hypoxemic patients with chronic obstructive pulmonary disease. Respiratory medicine, 98 (11), 1117-1123.

13. https://emedicine.medscape.com/article/205039overveiw dated on 28/6/2021 S.N Desai, F.F Farris, S.D Ray. Lipid peroxidation. Encyclopedia of Toxicology, $3^{\text {rd }}$ edition, Academic Press, 2014, Pp 89-93.

14. Suzy A, A.Comhair et al. Correlation of systemic superoxide dismutasedeficiency to airflow obstruction in asthma. American Journal of Respiratory and critical care medicine. 2005. Aug 1;172 (3): 306-313)

15. Kashinath shastri, gorakhanathachaturvedi.CharakasamhitaofAgnivesha.Part $\quad 1, \quad$ sutrasthana,chapter 26, verseno 43(4),1"edition,Varanasi,Chowkambha Bharati Academy, 1998(Reprint);507

16. Rama Rao, Astanga Sangraha of Vagbhata. $1^{\text {st }}$ edition. Varanasi. Chowkambha Vishwabharati, 2006. Vol 1, sutrasthana, chapter 17, verse 16, p270

\section{Source of Support: Nil \\ Conflict of Interest: None Declared}

How to cite this URL: Divya Shekar.B \& Surekha S Medikeri: Evaluation of Anti-Histaminic Activity Of Kasankusha Rasa In Guinea Pigs. International Ayurvedic Medical Journal \{online\} 2021 \{cited September 2021\} Available from: http://www.iamj.in/posts/images/upload/2037_2043.pdf 